\title{
Tolkning i forbindelse med politiafhøring. Problemer og mulige løsninger
}

Kristina Kepinska Jakobsen Høgskolelektor cand.psych.

Kristina.Kepinska.Jakobsen@phs.no

\section{Keywords}

interpreting police interview

K.R.E.A.T.I.V

cognitive interview

memory 


\begin{abstract}
In this article I present firstly the Norwegian training programme in investigative interviewing (K.R.E.A.T.I.V.), and secondly the concept of the cognitive interview (a method of interviewing witnesses and victims about what they remember from a crime scene). I argue that some of the techniques employed in both K.R.E.A.T.I.V. and the cognitive interview are problematic when communicating via an interpreter. In particular, this concerns the emphasis on the giving of a "free account", which means that the interviewee is given the opportunity to talk without being interrupted. I also present the results of a survey that was sent out to Norwegian police officers. The purpose of the survey was to gain insight into what police officers found challenging when interviewing. Many of the respondents referred to different aspects of communicating via an interpreter. Finally, I discuss some possible solutions to these challenges.
\end{abstract}




\section{Indledning}

Som følge af immigration og øget internationalisering bliver flere og flere afhøringer foretaget med tolk. Politifolk oplever det ofte som en ekstra udfordring, hvilket naturligvis kan skyldes at tolken ikke er kvalificeret eller at politiet ikke er uddannet tilstrækkeligt til at afhøre med tolk. Herudover er der forhold ved den afhøringspraksis, norsk politi benytter, der er vanskelige at gennemføre med tolk.

Jeg vil i denne artikel præsentere norsk politis afhørsmetodik og diskutere nogle af de problemstillinger, der er forbundet med at benytte tolk under afhøringer samt pege på mulige løsninger på disse. Som et led heri vil jeg trække på en spørgeskemaundersøgelse foretaget i 2012 blandt norske efterforskere.

\section{Norsk afhøringspraksis}

Afhøring er et af politiets vigtigste efterforskningsmetoder. Alligevel er det først i 1980erne at der fra forskellig side kom fokus på afhøringsteknikker. I England, som er et foregangsland inden for området, skete dette på grund af en række falske tilståelser blandt andet som følge af politiets afhøringsteknik. Dette førte i 1986 til, at alle afhøringer af sigtede skal optages på bånd, og at myndighederne indledte en granskning af afhøringspraksissen. På denne baggrund blev der i begyndelsen af 90 'erne udarbejdet et obligatorisk oplæringsprogram for britisk politi, som fik navnet PEACE (McGurk et al.,1993).

PEACE-kurset var et opgør med den tilståelsesbaserede tilgang til afhøring af sigtede som var fremherskende (og i mange lande stadig er udbredt). I stedet skulle formålet med afhøringen være at få så mange pålidelige informationer som mulig. Siden er der udviklet mange forskellige afhøringskurser på forskellig niveauer.

På samme tid blev en afhøringsform, det såkaldte kognitive interview, udviklet af to amerikanske kognitionspsykologer, Fisher og Geiselman (Fisher og Geiselman, 1992). Baggrunden for udviklingen af det kognitive interview er, at politiet i mange tilfælde er afhængige af så mange detaljer som muligt, som vidner, forurettede (og sigtede, hvis de vælger at fortælle) kan bidrage med. Både for at få et overordnet billede af, hvad der er sket, men også for at få små detaljer med, der i nogle tilfælde kan have stor betydning i efterforskningen og i den senere bevisvurdering. Formålet med det kognitive interview er at hjælpe vidner til at huske og få fortalt så meget de husker i en afhøring, uden at antallet af ukorrekte informationer stiger. Teknikkerne bygger på viden om den menneskelige hukommelse og er i dag udbredt i store dele af verdenen.

I Norge oplevede man en tilsvarende udvikling som i England efter blandt andet Karmøysagen. ${ }^{1}$ I slutningen af 1990 erne blev to norske efterforskere sendt på et studieophold $\mathrm{i}$ England, og i 2001 udviklede Asbjørn Rachlew et nyt oplæringsprogram, K.R.E.A.T.I.V. for Oslo Politi (Rachlew, 2011). Oplæringsprogrammet er inspireret af PEACE-kurset og bygger på forskningsbaserede metoder og indeholder en række emner som kommunikation, etik, menneskerettigheder, vidnepsykologi, det kognitive interview, jura, taktik og viden om falske tilståelser. ${ }^{2}$ Afhøring med tolk bliver også berørt på K.R.E.A.T.I.V-kurset, men da der

1 En sag fra 1995, hvor en 19årig mand tilstod drabet på sin kusine. Han blev først dømt for drabet. Senere trak han tilståelse tilbage og efterforskningen blev vurderet af to britiske eksperter, som vurderede afhøringer af ham som stærk manipulative og i 1998 blev han frikendt (for at læse mere om denne sag se: Gudjonsson, 2008)

2 Kommunikation, Retssikkerhed, Etik og Empati, Aktiv bevidstgøring, Tillid gennem åbenhed, Videnskabelig forankring. 
er mange emner, der skal gennemgås, bliver det snarere tale om en orientering end egentlig undervisning $\mathrm{i}$, hvordan man bedst afhører med tolk.

Den model, der undervises i omfatter seks faser, som gælder for alle afhøringer. Herudover undervises der i en taktisk afhøringsmodel, der kan anvendes når mistænkte afhøres, og det kognitive interview, der kan benyttes for at hjælpe den afhørte med at huske.

K.R.E.A.T.I.V. - modellen er altså grundlæggende, mens de to andre tilgange kan benyttes alt efter behov.

I det følgende vil K.R.E.A.T.I.V. - modellen kort blive præsenteret og herefter taktikmodellen samt det kognitive interview.

\section{K.R.E.A.T.I.V.}

KREATIV-modellen omfatter følgender faser:

En planlægningsfase, der blandt andet består $\mathrm{i}$ at læse sagens dokumenter, hvordan man vil gennemføre afhøringen og mentalt forberede sig på afhøringen. I denne fase kan afhøreren også forberede sig på at afhøringen skal tolkes.

En kontaktetableringsfase, hvor den afhørte oplyses om pligter og rettigheder og bliver gjort bekendt med sigtelsen, såfremt den afhørte er sigtet. Herudover skal afhøreren forklare den afhørte, hvordan afhøringen skal gennemføres, for eksempel hvad man forventer af den afhørte, og hvad man selv har tænkt sig at gøre. Endelig præsenteres alle tilstedeværende og rollerne afklares. Det er således i denne fase, at der er mulighed for at tolken eller afhøreren kan forklare den afhørte om de retningslinjer vedkommende arbejder efter.

Næste fase er den fri forklaring, hvor den afhørte opfordres til at give en sammenhængende fri forklaring og hvor det er vigtigt at afhørte ikke bliver afbrudt. Dette er centralt i K.R.E.A.T.I.V. og det er måske netop på dette punkt, at tolkning kan indebære problemer. Jeg skal i et senere afsnit vende tilbage til dette under afsnittet om frie forklaringer.

Efter den frie forklaring følger en sonderingsfase, hvor de forskellige temaer uddybes. Et tema kan omhandle en bestemt del af et hændelsesforløb eller det kan dreje sig om en beskrivelse af for eksempel en gerningsperson. Fremgangsmåden vil ofte være sådan, at den afhørte opfordres til en ny fri forklaring om et konkret afgrænset tema, som følges op med spørgsmål indtil afhøreren vurderer at han/hun har fået svar på alt af relevans om det pågældende tema. Efter hvert tema opsummerer afhøreren det centrale af det som afhørte har fortalt.

Herefter følger afs/utningsfasen, hvor afhøreren typisk vil orientere den afhørte om sagens videre forløb og afklare om den afhørte har nogle spørsmål.

Efter selve afhøringen følger en evalueringsfase, hvor de nye informationer, der er kommet frem, samt afhørerens egen indsats, evalueres. 


\section{Den taktiske model ${ }^{3}$}

Denne model benyttes når politiet er $\mathrm{i}$ besiddelse af potentielle beviser mod en bestemt person. Grundtanken er, at man gennem afhøringen skal søge klarlagt om den mistænkte er skyldig, helt uskyldig, eller spiller en anden rolle end politiet antager. Inden den mistænkte præsenteres med det/de potentielle beviser, skal man derfor fors $\varnothing g e$ at afklare om der er en anden mulig forklaring på disse end at den mistænkte er skyldig. I denne proces skal de potentielle beviser holdes tilbage, således at den skyldige mistænkte ikke kan tilpasse sine forklaringer til de beviser, der foreligger. Det er nemlig sværere at lyve og finde på en plausibel forklaring, når man ikke ved, hvilke informationer politiet har kendskab til. Hvis man derimod præsenterer den afhørte for det potentielle bevis for tidligt, kan den skyldige sigtede have held til at finde på en usand, men plausibel forklaring, der kan være svær eller umulig at tilbagevise. Hvis ikke den mistænkte under den frie forklaring eller en grundig sondering har præsenteret nogen alternativ forklaring, skal han præsenteres for det potentielle bevis, som således også normalt vil have en langt stærkere bevismæssig værdi. Taktikken er både effektiv og etisk, idet den egner sig til at knytte den skyldige mistænkte tættere til gerningen, men samtidig med sin åbne tilgang sikrer, at den afhørte får mulighed for at afgive sin forklaring. Den uskyldige sigtede har altså mulighed for at forklare, hvorfor det potentielle bevis ikke beviser hans skyld.

Fremgangsmåden kan inddeles i 4 faser. De 2 første faser hører til forberedelsesfasen, mens de to sidste gennemføres under selve afhøringen.

Fase 1. I den første fase skal sagsakterne gennemgås og samtlige potentielle beviser identificeres. Man skal altså danne sig et godt billede af, hvad sagen mod den sigtede består af og beslutte sig for, hvilke informationer man vil håndtere taktisk. Det optimale er, at alle informationer, der potentielt kan udgøre et bevis, håndteres taktisk. På dette tidlige tidspunkt er det væsentligt både at medtænke informationer, der knytter den sigtede til forbrydelse, og informationer, der renser den sigtede.

Fase 2. I denne fase skal alle tænkelige forklaringer på de potentielle beviser identificeres. Dette er også med til at sikre en åben tilgang, idet man herved forholder sig til alternative forklaringer, der rent faktisk kan være på det potentielle bevis. Hermed modvirker man "tunnelsyn", det vil sige at man fokuserer entydigt på en mulighed og dermed ubevidst udelukker andre forklaringer. Som nævnt ovenfor tager man herved metodisk højde for, at den sigtede kan have spillet en anden rolle end først antaget eller slet ikke har noget med forbrydelsen at gøre.

Fase 3. I denne fase skal man forsøge at eliminere de alternative forklaringer, som blev identificeret i fase 2, og alle forklaringer afgivet af den sigtede skal undersøges. Afhøreren skal forsøge at stille spørgsmålene, så den afhørte ikke kan regne ud, hvilke beviser politiet sidder inde med. Hvis spørgsmålet afslører, hvilke beviser politiet har, kan den kvikke afhørte måske aflure strategien og udtænke en plausibel forklaring, før politiet har haft mulighed for at eliminere den.

Fase 4. Når samtlige forklaringer er elimineret, præsenteres den afhørte for beviset og anmodes om en forklaring på dette.

Modellen kan lyde enkel men er krævende at gennemføre i praksis, idet afhøreren skal sikre, at han/hun har fået «lukket» alle potentielle forklaringer, uden at have afsløret overfor sigtede, hvilke potentielle beviser man er i besiddelse af. Dette gør at spørgsmålenes formulering kan have afgørende betydning og politiet ønsker derfor at tolken

3 Beskrivelsen af taktikmodellen er hentet fra Fahsing og Rachlew, 2006 og 2009. 
oversætter «ord for ord». Men som regel er det ikke muligt at oversætte «ord for ord» fra et sprog til et andet, da sprog er opbygget forskelligt. Dette kan føre til at det oversatte spørgsmål ikke er så præcist og nøje afgrænset, som det oprindelige norske spørgsmål.

\section{Det kognitive interview}

Udover de beskrevne faser og taktikmodellen kan afhøreren også benytte sig af elementer af det kognitive interview.

Den første udgave af det kognitive interview bestod af fire principper, men det blev senere videreudviklet og kaldt The Enhanced Cognitive Interview. I dag er det oftest den nye og forbedrede udgave man refererer til, når man omtaler det kognitive interview.

Den første udgave omfattede følgende fire principper:

- Den afhørte opfordres til mentalt at forsøge at genskabe konteksten for indkodningstidspunktet, det vil sige det tidspunkt de overværede den hændelse, de skal fortælle om. Dette gælder både den ydre kontekst, som for eksempel lyde, lysforhold og lugte samt den indre kontekst som følelser og tanker. På denne måde kan afhørte få en oplevelse af mentalt at være tilbage på det fysiske gerningssted på gerningstidspunktet.

- Den afhørte opfordres til at fortælle om alle de detaljer de husker, uanset om de opfatter informationerne som relevante eller ej.

- Den afhørte opfordres til at fortælle om forløbet i forskellig rækkefølge. For eksempel kan den afhørte opfordres til at fortælle om hændelsen i den modsatte rækkefølge eller starte ved det mest dramatiske tidspunkt og derfra gå både frem og tilbage i tiden, således at den tidsmæssige kronologi ikke følges.

- Den afhørte opfordres til at fortælle ud fra forskellige perspektiver. Vidnet har måske set en gerningsmand fra forskellige geografske positioner og opforders til at indtage og fortælle ud fra et perspektiv ad gangen.

Den senere udgave består af en faseinddelt model, hvor der udover de fire principper er lagt vægt på kontaktetablering og kommunikationen mellem afhører og den afhørte. Faserne er som følger: fase 1: kontaktetablering, fase 2: forklar formålet med afhøringen, fase 3:genskab konteksten og den fri forklaring, fase 4: spørgsmål, fase 5: forskellige genkaldelsesforsøg (skift rækkefølge, skift perspektiv), fase 6: opsummering, fase 7: afslutning. Det centrale er, at det er den afhørte, der skal være aktiv og fortælle frit, og ikke afbrydes. Hertil skal afhøreren primært benytte sig af åbne spørgsmål og undgå lukkede og ledende spørsmål. Flere af disse kommunikationselementer er indarbejdet $\mathrm{i}$ K.R.E.A.T.I.V, mens de oprindelige principper er unikke for det kognitive interview.

\subsection{Teoretiske antagelser der ligger til grund for det kognitive interview}

I det følgende vil jeg redegøre for nogle af de teoretiske antagelser, der ligger til grund for det kognitive interview.

Overordnet set tages der i det kognitive interview udgangspunkt i, at der er tre grundlæggende årsager til glemsel.

For det første kan glemsel skyldes svind, hvilket vil sige, at informationerne eller "hukommelsessporet" ikke længere er lagret. Dette skyldes, at hukommelsesspor svækkes 
over tid med mindre de med jævne mellemrum genopfriskes. Dette vil især gøre sig gældende for perifere detaljer og oplevelser, der ikke har gjort særligt indtryk på personen.

For det andet kan glemsel skyldes at man ikke kan skelne mellem forskellige ensartede erindringer. Dette kan bevirke, at detaljer ved de enkelte episoder glemmes eller at detaljer vedrørende en episode blandes ind i erindringen af andre episoder. For eksempel kan det være vanskeligt for personer, der gentagne gange udsættes for vold af deres samlever, at skelne mellem de forskellige voldsepisoder. I sådanne tilfælde vil vedkommende udvikle et script for vold, så personen husker hvordan det plejer at foregå, men på bekostning af præcise detaljer for hver enkel episode. Noget lignende kan ske hvis man først oplever for eksempel et røveri, og senere snakker med andre vidner om hændelsen og ad den vej hører om nye detaljer. Disse nye informationer vil muligvis integreres i erindringen og personen vil ikke længere kunne skelne mellem hvad vedkommende har set og hvad han/hun senere har hørt.

En tredje årsag til at man ikke kan huske en given information kan være, at hukommelsessporet stadig er lagret, men ikke umiddelbart tilgængeligt. Sådanne hukommelsesspor kan der muligvis skabes adgang til ved anvendelsen af søgestrategier eller ved præsentation af relevante cues (Tulving, 1973).

Der skelnes således mellem lagret information, der er til rådighed, og lagret information, der er tilgængelig. Tilgængelig information er det man kan huske uden videre, mens information, der er til rådighed men ikke tilgængelig, ikke uden videre vil kunne huskes under fri genkaldelse. Det betyder, at vidner faktisk kan have registreret flere informationer og have flere informationer til rådighed end de i første omgang fortæller, men at disse kun kommer frem hvis de făr tid og hjælp til at skabe adgang til disse informationer. Teknikkerne $\mathrm{i}$ det kognitive interview sigter på at gøre alle de hukommelsesrepræsentationer, der er til rådighed, tilgængelige. Hukommelsesrepræsentationernes utilgængelighed kan skyldes overfladisk og mangelfuld søgning og principperne er udviklet til at give den afhørte flere søgestrategier for derved at gøre søgningen mere effektiv.

En måde at gøre ikke tilgængelig information tilgængelig er ved at udnytte genkaldelsescues. Det, der gør et cue virkningsfuldt, er hvis det er blevet indkodet på samme tidspunkt som det, der skal huskes. Det vil sige at alt, hvad der forekom, og som ligeledes blev indkodet på indkodningstidspunktet, kan fungere som genkaldelsescues. Genkaldesescuet behøver ikke at have nogen betydning i forhold til det, der skal huskes. Det afgørende er at det blev indkodet samtidig. Den hukommelsesrepræsentation, der lagres indeholder altså dels det-der-skal-huskes, men også andre elementer i konteksten. Og disse elementer vil kunne fungere som effektive genkaldelsescues (Tulving, 1983). For eksempel kan regnvejr virke som et genkaldelsescue, hvis det regnede på indkodningstidspunktet og også regner på genkaldelsestidspunktet, uanset om regnvejr har noget med den givne information at gøre. Andre eksempler kunne være en lugt af en gerningsmand, der kan virke som et genkaldelsescue, selv om lugten intet har at gøre med den handling, den pågældende har udført.

De fleste har nok oplevet denne form for kontekstafhængig hukommelse. Hvis man for eksempel besøger sin gamle skole, vil mange nok huske begivenheder og personer, man ikke har skænket en tanke siden den gang man gik i skole, og som man ikke var klar over at man kunne huske. Det at befinde sig i samme omgivelser (ydre kontekst), som da man oplevede tingene, kan skabe adgang til erindringer, som altså var til rådighed men ikke umiddelbart tilgængelige før.

I det kognitive interview sigtes der på mentalt at genskabe konteksten for indkodningstidspunktet frem for fysisk at vende tilbage til gerningsstedet. 
Det at genskabe konteksten for indkodningstidspunktet er en hensigtsmæssig teknik overfor de egentlige øjenvidner, som for eksempel et øjenvidne, der har overværet et røveri. I sådanne tilfælde vil der være tale om episodiske erindringer. Det vil sige selvoplevede oplevelser, som netop er knyttet til tid og sted. ${ }^{4}$

\section{Frie forklaringer}

Et grundliggende princip i såvel K.R.E.A.T.I.V. som i det kognitive interview er, at den afhørte skal fortælle frit uden afbrydelser, tidspres eller ledende spørsmål. Dette er der flere grunde til.

For det første kan det at fortælle detaljeret om en given hændelse medvirke til at genskabe konteksten for indkodningstidspunktet. Som beskrevet i ovenstående kan aktiveringen af en type information aktivere andre informationer og således øge mængden af, hvad der huskes.

Hvis den afhørte derimod bliver afbrudt, vil man stoppe søgningen i hukommelsen og den afhørte vil dermed komme i tanke om færre informationer.

For det andet vil det man fortæller frit uden at have fået stillet lukkede og ledende spørsmål, ofte være mere korrekte (Kebbel \& Waagstaff, 1999).

For det tredje kan den afhørte holde information tilbage, fordi den pågældende antager, at politiet allerede kender til de givne forhold, at informationerne er irrelevante, eller opfatter nogle forhold som åbenlyse. Mange mennesker vil, når de gengiver et hændelsesforløb, fokusere på de centrale detaljer, der giver situationen mening, og undlade mange, især perifere detaljer, fordi de forekommer irrelevante for handlingen, selv om man måske husker dem. Men af og til er det tilsyneladende perifere detaljer, der kan stor betydning for efterforskningen.

For det fjerde ved afhøreren oftest ikke hvad og hvor meget den afhørte ved, har set eller hørt. Hvis afhøringen gennemføres ved at afhøreren stiller en lang række lukkede spørgsmål vil spørgsmålene ofte komme til at afspejle egne forventninger og formodninger om, hvad vidnet har set og hørt. Disse formodninger kan måske være velbegrundede, i og med at afhøreren måske har hørt andre vidner fortælle om hændelsesforløbet eller har viden fra tekniske beviser. Men afhørerens forståelse af den givne situation kan afvige fra det, som netop denne afhørte har indkodet, eller fra, hvor meget afhørte er i stand til at genkalde sig. Kort sagt risikerer man kun at få svar på det der spørges om og derved at gå glip af anden information, som kan være vigtig.

Denne vægt på frie forklaringer er potentielt problematisk, når der benyttes tolk $\mathrm{i}$ afhøringen. Først og fremmest i den første frie forklaring, der i nogle tilfælde kan vare i 45 minutter eller mere. Men også i sonderingsfasen, hvor den afhørte i nogle tilfælde vil forklare sig længe om et emne. Få tolke klarer at notere en monolog der varer 45 minutter. Og som en ekstra udfordring ønsker politiet ikke et sammendrag, men derimod en nøjagtig oversættelse af det, som den afhørte siger. Dette betyder, at tolken ikke altid kan vente med at oversætte til den afhørte er færdig, men må bryde ind og oversætte dele af forklaringen, da tolken må afstemme sekvenslængden efter egen hukommelseskapacitet (Skaaden, 2013). En anden mulighed er at bruge simultantolkning. Men ulempen er her, at en del information forsvinder når man tolker simultant. Der er altså en udfordring i denne fase, hvor pointen netop er, at den afhørte ikke skal afbrydes og politet ønsker at alt bliver tolket. Der er forskel på hvor store «bidder» en tolk kan lytte til før vedkommende må

4 Herudover findes der også to andre former for hukommelsessystemer, nemlig den semantiske, der indeholder vores ordforråd og almene viden og den procedurale, der omhandler vores hukommelse for at udføre handlinger, for eksempel at cykle. 
tolke, men det vil under alle omstændigheder medføre, at den afhørte ikke kan forklare sig så frit som det er målet i K.R.E.A.T.I.V.

\section{Spørgeundersøgelse blandt norske afhørere}

I 2002 overtog Politihøgskolen K.R.E.A.T.I.V.- kurset fra Oslo Politi og det er således Politihøgskolen, der har ansvar for at uddanne instruktører, der gennemfører K.R.E.A.T.I.V.kurser i politidistrikterne. Der findes i dag omkring 100 instruktører og omkring 2000 efterforskere, der har gennemført kurset.

I 2012 blev det besluttet at udvikle nye afhøringsstudier, der skulle bygge videre på K.R.E.A.T.I.V. I den forbindelse udarbejdede denne artikels forfatter et spørgeskema. Ønsket var at få besvarelser fra alle efterforskere, der har gennemgået K.R.E.A.T.I.V.kurset, for at få indblik i dagens praksis. Formålet med undersøgelsen var altså ikke at forske i politiets brug af tolk, men at indhente viden, der ville kvalificere udviklingen af nye afhøringsstudier. Flere af respondenterne gav imidlertid svar, der er interessante ud fra et tolkeperspektiv og vil derfor blive refereret her. Dette er første gang at resultaterne gengives i en artikel. Svarene er anonymiseret og kan ikke spores tilbage til respondenterne.

Skemaet blev sendt pr. mail til samtlige K.R.E.A.T.I.V.-instruktører, der blev opfordret til at videresende det til de efterforskere, de havde haft på kursus. Det var imidlertid tidskrævende for mange instruktører at finde frem til tidligere kursister. Dette sammenholdt med, at spørgeskemaet var relativt omfattende, forklarer formentlig at der var en meget lav svarprocent. Der var således kun 164 respondenter ud af de omkring 2000 efterforskere, der har gennemgået K.R.E.A.T.I.V.-kurset, som besvarede spørgeskemaet. Dette betyder at resultaterne ikke nødvendigvis er repræsentative. Respondenterne havde dog forskellig baggrund med hensyn til erfaring, arbejdssted og arbejdsområder, hvilket kan give et bredt billede af norske efterforskeres erfaringer med afhøring gennem tolk. Denne antagelse understøttes af, at de erfaringer som respondenterne giver udtryk for stemmer godt overens med, hvad jeg som underviser i afhøringsteknikker både i Danmark og Norge

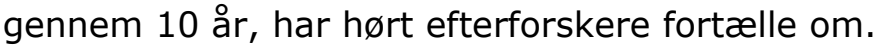

Hovedparten af spørgsmålene $i$ skemaet omhandlede hvilke af faserne i K.R.E.A.T.I.V.modellen efterforskerne oplever som enkle og hvilke de oplever som krævende at implementere i reelle afhøringer. Det sidste spørgsmål i spørgeskemaet var åbent og formuleret således:

«Det siste spørsmalet handler om spesielle avhørssituasjoner. Det vil si avhørssituasjoner, som du synes er særlig krevende, eller som avviker fra vanlige avhør. Det kan både omhandle bestemte sakstyper, avhørtes status, alder, personlighet, eller øvrige forhold ved etterforskningen. Dette er kun noen av mange mulige situasjoner. Spørsmålet er altså helt åpent og opp til deg å besvare. Hvilke avhørssituasjoner, mener du er spesielt utfordrende, og hva er det, som eventuelt gjør dem spesielt utfordrende?»

Et af de hyppigste svar omhandlede afhøring med tolk eller afhøring af personer med anden etnisk baggrund end norsk. Disse svar blev kategoriseret og særlig fire problemstillinger synes at være fremherskende, nemlig tolkenes kvalitet, kulturelle faktorer, muligheden for at skabe kontakt og problemet med afhøringsteknikker, når man afhører med tolk. 


\section{Kvalitet}

Når det kommer til selve tolkens kvalifikationer nævner flere, at de oplever varierende kvalitet og at der ofte opstår tvivl og uenighed i retten om, hvad der præcist er blevet sagt.

Tre respondenter skriver således:

- Alle avhør der man må benytte tolk. Her blir budskapet alltid forvrengt på ett eller annet vis

- Avhør med tolk er spesielt utfordrende. Det tar lang tid og fører av og til til uenighet i retten rundt hva som ble sagt. Det er svært varierende kvalitet på forskjellige tolker

- Tolken kan gi feil nyanser i oversettingen.

I andre svar forholder respondenterne sig kritisk til tolkenes rolleforståelse:

- Bruk av tolk. De kan ha andre agendaer og forståelser av situasjonen enn oss

- I tillegg er en del tolker ikke gode i rollen sin

Man kan spørge sig selv på hvilket grundlag respondenterne bedømmer tolkens kvalifikationer. De kan selvfølgelig bedømme tolkens norskkundskaber og have en oplevelse af hvor «flydende» samtalen foregår og om det tolkede kommer i markant kortere sekvenser end det som siges af henholdsvis politi og den afhørte. Eller omvendt, hvis korte sætninger gengives med mange ord - uden at årsagen til dette bliver forklaret af tolken. Men politiet har jo faktisk ikke mange muligheder for at vurdere, hvordan det sagte bliver oversat.

En vis sikring af kvaliteten har politiet i de tilfælde, hvor afhøringen bliver optaget. Dette vil oftest ske i alvorlige sager. Det vil sige, at i de tilfælde, der opstår tvivl om tolkningen eller den afhørte mener sig misforstået er det muligt at kontrollere, hvad der præcist blev sagt og hvordan det blev tolket.

Ud fra svarene kan man få en mistanke om, at der af og til benyttes ukvalificerede tolke. Dette kan både skyldes at politiet ikke aktivt forsøger kun at benytte sig af statsautorisrede/uddannede tolke - måske på grund af manglende bevidsthed om forskellene på tolkes uddannelsesniveau. Men det kan også skyldes mere praktiske omstændigheder. For eksempel, at der ikke findes autoriserede tolke i alle sprog og da de der er, ikke er lige tilgængelige alle steder i landet. Samtidig har politiet ofte en stram tidsramme og har i disse tilfælde ofte ikke mange valg. I nogle tilfælde er eneste mulighed telefontolkning eller videokonference. At politiet bruger telefontolkning kan også være begrundet i økonomiske hensyn, særlig i tilfælde, hvor det er vanskeligt og kostbart at få tolken til at møde personligt.

Spørgsmålet om kvalitet handler dels om tolkens kavlifikationer og professionalitet. Men også om de arbejdsbetingelser tolken arbejder under. En respondent skriver såldes:

- Jeg synes avhørssituasjoner med tolk kan være utfordrende. I våre saker er det mange tekniske terminologier og faguttrykk som er krevende for tolken at sette seg inn i.

Her kan problemet både skyldes, at tolken er ukvalificeret, men det kan også skyldes at brugeren af tolken (altså politiet) ikke har givet tolken den fornødne tid til at forberede sig, for netop at kunne sætte sig ind i fagudtryk. 
Der findes så vidt vides ikke en oversigt over, hvilke tolke politiet benytter sig af. Men i en rapport fra 2012 dokumenteres det, at problemet med at brugen af ukvalificerede tolke er udbredt i dele af den offentlige sektor, herunder sygehusvæsenet og domstolene (Linnestad \& Buzungu, 2012).

\section{Kulturelle faktorer}

Flere problemstillinger omhandler kulturelt betingede forskelle mellem en henholdsvis «norsk» måde at opføre sig på under afhøring, og en «ikke-norsk» måde. For eksempel, hvor direkte den afhørte svarer på spørgsmål eller hvor meget den afhørte «snakker udenom» og kommer med lange omveje.

- Avhør av "utlendinger". Det er ofte vanskelig å få en lang fri forklaring av dem, spesielt med bruk av tolk. Det er også vanskelig å få et konkret svar på spørsmål da de ofte «går rundt om grøten» og snakker om mye annet.

Andre beskriver at «ikke-norske» borgeres forhold til politiet kan påvirke dialogen negativt under afhøringen:

- Utlendinger med dårlig erfaring fra lokalt politi som ikke gir deg nok tillit og tror du ønsker å skade dem.

- De mest utfordrende avhørene har vært av personer som er mistenkt med annen kulturell bakgrunn. Det å kunne forstå svarene som disse gir utifra usikkerheten om de svarer kun for at «please» med som avhører eller om et ja egentlig betyr nei, men i deres kultur svarer en aldri nei på et spørsmål.

- Avhør med fremmedkulturelle. Disse har ofte svært lite forståelse for hvordan vårt rettssystem fungerer, og virker svært mistroiske overfor politiet (forståelig nok).

En respondent skriver:

- Avhør av personer som har en helt annen kulturbakgrunn enn meg selv. Noen kulturer har jeg etter hvert lært meg mye om. Andre kulturer kan jeg for lite om, men jeg er nysgjerrig og det hjelper.

Disse problemstillinger betyder altså at politiet oplever, at de ikke kan gennemføre afhøringerne som de vanligvis ville gøre, men det sidste citat peger på et ønske om at lære om det man ikke ved nok om. Det er klart at nysgerrighed ikke løser alle problemstillinger, der knytter sig til det at afhøre folk med anden kulturel baggrund end sin egen. Men det kan hjælpe. Særlig i foreredelsesfasen kan efterforskeren indhente viden om afhørtes kulturelle baggrund og om der er forhold man kan tage højde for. Jo mere bevidst afhøreren er om de problemstillinger der kan være, jo bedre vil vedkommende kunne håndtere det under afhøringen. For eksempel ved at være meget tydelig om pligter og rettigheder, og om hvordan man ønsker at gennemføre afhøret. Eller ved på den ene side være forberedt på og «tillade» omveje for at nå til sagens kerne, men også af og til være mere styrende og stille mere afgrænsede spørgsmål end man normalt ville gøre.

Sammenfattende peger resultaterne på, at politiet oplever en række problemer på grund af kulturforskelle. Spørgsmålet er imidlertid, om de oplevede udfordringer altid omhandler kulturelle faktorer. Felberg og Skaaden (2012) beskriver således en tendens hos tolkebrugere til at tilskrive oplevede problemer i kommunikationen som kulturelt betinget, hvor det måske i nogle tilfælde skyldes andre årsager. 


\section{Kontakt}

Flere af respondenterne nævner den forringede mulighed for at opnå en god kontakt.

- Avhørssituasjoner med tolk opplever jeg som utfordrende, da det er veldig hemmende for kommunikasjonen med den avhørte.

- Avhør av personer med tolk. Da blir det fort vanskelig å komme innpå den man avhører. Disse avhørere blir mer masseproduksjon og man kjører gjennom avhørene for å bli ferdig.

- Avhør med tolk kan være krevende. Det er ofte vanskelig å få tilstrekkelig kontakt med den avhørte pga tolken.

Respondenterne oplever altså, at at det hæmmer kommunikationen med den afhørte, når al kommunikation går gennem en tredje part. Svarene er ikke overraskende og det kan synes vanskeligt at omgå dette forhold. For at skabe de bedst mulige forudsætninger for at opnå en god kontakt kan en mulighed være at have et formøde med tolken og derved lære tolken at kende og etablere samarbejdet. Samt bruge mere tid i kontaktetableringen, end man plejer at gøre, for at skabe den tryghed hos den afhørte, som er nødvendig for at kontakten bliver god - eller så god, som det er muligt.

\section{Afhøringsteknikker}

Flere respondenter peger på, at det kan være vanskelig at benytte den taktiske model og kognitive teknikker, da tolken ofte ikke kender til disse og at der derved let kan opstå misforståelser.

- Avhør med tolk - hvordan bruke kognitive teknikker da?

- For eksempel føler jeg at mye av trykket i en konfrontering forsvinner ved bruk av tolk. For den siktede blir tolken «en krykke» som de kan bruke til å kjøpe seg tid.

- Det er vanskelig med kognitiv avhør når tolk er tilstede fordi tolken ikke kjenner «tilbakesettingen», og det blir en diskusjon mellom tolk og avhørte før en selv får forklaringen på temaet/spørsmålet og det er nesten umulig å «holde dem ikke i sitt eget hode» slik at de ser alt for seg når de forklarer seg når en bruker tolk.

En løsning, særlig ved længerevarende og komplicerede afhøringer, hvor man gerne vil benytte sig af kognitive teknikker eller den taktiske interviewmodel, kunne være at have en længere samtale med tolken før afhøringen, hvor man forklarer om principperne og afklarer samarbejdet. Man må dog tage højde for, at det centrale i kognitive teknikker er komplekst og i grunden uforeneligt med tolkning og at der derfor kun kan blive tale om tillempede former for kognitive teknikker. Længere samtaler kan forekomme ressourcekrævende, og alt afhængigt af, hvor vigtig afhøringen er, må man foretage en helhedsvurdering af behovet for dette. Det kan tilføjes, at hvis man skal gennemføre flere afhøringer med samme tolk, vil et sådant møde kun være nødvendigt en gang, og hvis der er tale om en tolk, der hyppigt tolker for politiet vil tolken således have lært om politiets arbejdsmetoder til de næste afhøringer. 


\section{Vejen videre frem}

Respondenterne i spørgeskemaundersøgelsen angav som beskrevet forskellige udfordringer ved afhøring med tolk. En del af problemerne er vanskelige at løse, hvis det overhovedet lader sig gøre, mens andre formentlig kan overkommes ved begrænsede tiltag. Men uanset hvor begrænsede eller omfattende tiltag der kommer på tale, indebærer tolkning - og forbedring af kvaliteten af tolkning - et krav om ekstra ressourcer blandt andet $\mathrm{i}$ form af politifolks arbejdstid. Det skal dog her bemærkes, at hvis man undlader at bruge tolk eller ikke tolken korrekt kan det forlænge processen og på dermed ende med at bliev en større udgift.

En afgørende forudsætning for forbedringer vil være at begge aktører kender til hinandens arbejdsmetoder og at der er enighed om fremgangsmåden. Det at man kender til hinandens arbejdssituation vil medføre, at man kan tage fælles ansvar for at afhøringen forløber bedst mulig. Som det er nu, vil aktørerne have varierende grad af viden og forståelse for hinandens rolle og, det er derfor præget af tilfældighed, hvem - og om nogen - der påtager sig ansvaret for forløbet.

Som minimum må rollerne og fremgangsmåde afklares ved afhøringens begyndelse og afhøreren må tilpasse sin fremgangsmåde til det forhold, at afhøringen gennemføres med tolk. Dette er allerede angivet i Utlendingsdirektoratets publikation: «Kommunkasjon va tolk« fra 2003.

En anden og mere ambitiøs mulighed er en målrettet uddannelse af såvel tolke som afhørere. Som allerede beskrevet skulle spørgeundersøgelsens resultater bruges i udviklingen af nye afhøringsuddannelser. I første omgang er der udviklet et studie, «Videreutdanning $\mathrm{i}$ avhørsutdannening. Fellesmodul» (10 studiepoeng). Studiet retter sig mod alle efterforskere, der afhører som en del af deres hverdag. Dette første trin er et generaliststudie og emnerne omfatter både taktik, hukommelse, kognitive teknikker, traumatiske hændelser, protokollering, vidnekonfrontation og afhøring med tolk. Studiet skal danne grundlag for videre påbygningsmoduler på specialistniveau, som skal udvikles $\mathrm{i}$ løbet af de næste par år. Blandt andet er der planer om at udvikle et studie, der udelukkende vil omhandle afhøring med tolk og afhøring af personer med anden kulturel baggrund end norsk. Dette studie vil være rettet til efterforskere, der ofte afhører med tolk.

I forbindelse med udviklingen af fællesmodulet har Politihøgskolen og Høgskolen i Oslo og Akershus indledt et samarbejde, der indebærer at Høgskolen varetager undervisningen i afhøring med tolk på fællesmodulet. Det er planen at repræsentanter fra Politihøgskolen skal undervise tolkestudenter i afhøringsteknikker på Høgskolen i Oslo og Akershus, for på denne måde at forbedre samarbejdet mellem politi og tolke (Felberg, 2013). 


\section{Referanser}

Fahsing, I. \& Rachlew, A. (2006) Etiske og effektive avhør av mistenkte. Kronik $i$ Politiforum. Juni/juli 2006, p. 32-33.

Fahsing, I. \& Rachlew, A. (2009) Investigative interviewing in the Nordic region. I: Williamson, T., Milne, B. \& Savage, S.P. (Eds.) International developments in Investigative Interviewing. William Publising.

Felberg, T. R. (2013) Kommunikasjon via tolk for offentlig ansatte. HiAO Rapport. Høgskolen i Oslo og Akershus

Felberg, T.R. \& Skaaden, H. (2012) The (de)construction of culture in interpreter-mediated medical discourse, I: Montalt, V. \& Shuttleworth, M. (Eds.) Translation and Knowledge Mediation Medical and Health Setting. Department of translators \& interpreters, Artesis University College.

Fisher, R.P. \& Geiselman, R.E (1992) Memory-enhancing techniques for investigative interviewing. Springfield: Charles C. Thomas

Gudjonsson, G. (2008) The Psychology of interrogations and confessing. A Handbook. John Wiley \& Sons Ltd.

Kebbell, M. \& Wagstaff, G. (1999) Face value? Evaluation the Accuracy of Eyewitness Information. Police Research Series paper, 102. Home Office

Linnestad, H. \& Buzungu, H.F. (2012). Likeverdige helsetjenester: Ikke lenger «en tjeneste av ukjent kvalitet» Statusrapport om tolkefeltet i helsevesenet i hovedstadsområdet. Helse Sør-øst. Oslo: Oslo kommune. Hentet 8.august 2014: http://www.tolkeportalen.no/Documents/Rapporter/.pdf

McGurk, B.J., Carr, M.J. \& McGurk, D. (1993) Investigative Interviewing Course of Police Officers: An Evaluation. Hentet 8.august 2014: http://tna.europarchive.org.pdf

Rachlew, A. (2011) Politiavhøret - en beretning fra innsiden. I: Kvalheim, G. Hjelpe meg! En bok om voldtekt. Stavanger: Hertervig forlag

Skaaden, H. (2013) Den topartiske tolken. Lærebok i tolking. Oslo: Universitetsforlaget.

Tulving, E. \& Thomson, D.M. (1973) Encoding specificity and retrieval in episodic memory. Psychology Review, 80, p.352-373.

http://dx.doi.org/10.1037/h0020071

Tulving, E. (1983) Element of episodic memory. Oxford: Claredon.

Utlendingedirektoratet (2003) Kommunikasjon via Tolk, temahefte 11, Utlendingedirektoratet. Hentet 8. august 2014:

http://www.tolkeportalen.no/Global/tolking/kommunikasjon_via_tolk.pdf 